\title{
The effects of ovalbumin as a protein source during the in vitro production of bovine embryos
}

\author{
Tatiane Almeida Drummond Tetzner ${ }^{1}$, Naiara Zoccal Saraiva ${ }^{1}$, Felipe Perecin ${ }^{2}$, Simone Cristina \\ Méo Niciura ${ }^{3}$, Christina Ramires Ferreira $^{4}$, Clara Slade Oliveira $^{1}$, Joaquim Mansano Garcia ${ }^{1}$ \\ 1 Departamento de Reprodução Animal, FCAV, UNESP, Jaboticabal, Brasil. \\ 2 Faculdade de Zootecnia e Engenharia de Alimentos, FZEA, USP, Pirassununga, Brasil. \\ ${ }^{3}$ Embrapa Pecuária Sudeste, São Carlos, Brasil. \\ ${ }^{4}$ Departamento de Química Orgânica, Instituto de Química, UNICAMP, Campinas, Brasil.
}

\begin{abstract}
Embryo quality is influenced by the culture conditions that affect in vitro maturation (IVM), fertilization (IVF) and culture (IVC) rates. The present study investigated the feasibility of producing bovine embryos after the replacement of fetal calf serum (FCS) and bovine serum albumin (BSA) by ovalbumin (OVA). The IVM and IVC medium were supplemented with $10 \% \mathrm{FCS}, 4 \mathrm{mg} / \mathrm{mL}$ BSA, or $4 \mathrm{mg} / \mathrm{mL}$ OVA. The IVF medium was supplemented with $6 \mathrm{mg} / \mathrm{mL}$ BSA or OVA. For IVM, supplementation with FCS, BSA, and OVA did not affect nuclear maturation or cortical granule migration. Higher rates of formation of two pronuclei were obtained when FCS was employed for IVM (79.97\%), regardless of the supplement used for IVF, and when BSA was used for IVF (59.4\%), regardless of the supplement used for IVM Supplementation with OVA for IVM+IVC $(20.40 \%)$ and for IVF $(22.15 \%)$ was inferior to supplementation with FCS for IVM+IVC (30.47\%) and with BSA for IVF (28.91\%) for blastocyst development. Hatching rates were lower using OVA for IVM+IVC (23.02\%) and for IVF (28.93\%) compared with FCS and BSA under the same conditions (40.78 and $34.82 \%$, respectively) and BSA for IVF (36.82\%). Supplementation with OVA for IVM+IVC and IVF resulted in reduced inner cell mass, trophectoderm cells and total blastocyst cell numbers $(17.29,37.88$, and 55.17, respectively). In conclusion, OVA is a protein source for bovine in vitro embryo production, although the quantity and quality of bovine blastocysts using only ovalbumin in the entire in vitro production process are lower than those obtained in the presence of FCS and BSA, when used as supplements in any step of bovine in vitro embryo production.
\end{abstract}

Key Words: bovine embryo, in vitro culture, ovalbumin, protein source

\section{Introduction}

In vitro production of bovine embryos enables greater reproductive use of genetically superior animals and reduces the interval generation, improving animal breeding. Thus, studies investigating the three steps of in vitro embryo production (IVP) are necessary to try to achieve results comparable to those obtained in vivo.

The culture media used for mammalian embryo development are conventionally supplemented with fetal calf serum (FCS) or bovine serum albumin (BSA) (Bavister et al., 1992; Gardner \& Lane, 1993). FCS and BSA are complex, undefined mixtures of different proteins, which contain small peptides, energy substrates and growth factors (Chaudhry et al., 2008, Kane \& Headon, 1980; Pratten et al., 1988). However, because BSA and FCS are prepared and purified from bovine blood products, they present a high risk of contamination by pathogens, viruses (Guerin et al., 1988), and prions (Batt et al., 1991; Krisher et al., 1999).
Thus, alternative supplements have been evaluated to replace BSA and FCS during IVP in order to avoid crosscontamination. The most commonly defined supplements used for IVP are synthetic macromolecules, such as polyvinyl alcohol (PVA) and polyvinylpyrrolidone (PVP) (Takahashi \& First, 1992; Wrenzycki et al., 1999). However, the results are controversial, and the quantity and quality of the embryos produced are often unsatisfactory.

Therefore, in the present study, ovalbumin (OVA), a protein source that has not been previously reported for bovine embryo IVP was evaluated. Ovalbumin, the main protein component of albumen (54\%), is a phosphoprotein whose synthesis is stimulated by estrogen (Bahr \& Johnson, 1991). Ovalbumin contains all essential amino acids (Besler \& Mine, 1999). Thus, OVA is a protein supplement that can maintain cell proliferation (Barlian et al., 1993). In addition, the risks of transmission of diseases to cattle are lower because of the heterologous (avian) origin ofOVA. 
The objective of the present study was to compare the effects of OVA and bovine blood proteins (FCS and BSA) on the IVP. The effects of OVA on nuclear and cytoplasmic maturation, pronuclear formation, embryo cleavage rates, blastocyst development, hatching rates and numbers of cells were carefully investigated.

\section{Material and Methods}

Chemicals and media were purchased from SigmaAldrich Chemical Company (St. Louis, MO, USA).

Bovine oocytes were collected by follicular aspiration from ovaries obtained at a local slaughterhouse and transported to the laboratory in $0.9 \%$ saline at $30-35{ }^{\circ} \mathrm{C}$. Follicles measuring 3 to $8 \mathrm{~mm}$ in diameter were aspirated with an 18 -gauge needle connected to a $20-\mathrm{mL}$ syringe. Cumulus-oocyte complexes with at least three cell layers and homogenous cytoplasm were selected and washed in HEPES-buffered tissue culture medium 199 (TCM-199; Gibco-BRL, Grand Island, NY, USA) supplemented with $10 \%$ FCS (Crypion, Andradina, Brazil), $0.20 \mathrm{mM}$ sodium pyruvate, and $83.4 \mu \mathrm{g} / \mathrm{mL}$ amikacin (Instituto Biochimico, Rio de Janeiro, Brazil).

For IVM, groups of 40-50 oocytes were cultured in $400 \mu \mathrm{L}$ of TCM-199 containing Earle's salts (Gibco-BRL), $1.0 \mu \mathrm{g} / \mathrm{mL}$ FSH (Folltropin ${ }^{\mathrm{TM}}$, Bioniche Animal Health, Belleville, Canada), $50 \mathrm{IU} / \mathrm{mL}$ hCG (Profasi ${ }^{\mathrm{TM}}$, Serono, São Paulo, Brazil), $1.0 \mu \mathrm{g} / \mathrm{mL}$ estradiol, $0.2 \mathrm{mM}$ sodium pyruvate, and $83.4 \mu \mathrm{g} / \mathrm{mL}$ amikacin under mineral oil (Dow Corning Co., Midland, MI, USA) in 4-well dishes (Nunc, Rochester, $\mathrm{NY}, \mathrm{USA}$ ) for $24 \mathrm{~h}$ at $38.5^{\circ} \mathrm{C}$ in $5 \% \mathrm{CO}_{2}$ in the air. The IVM medium was supplemented with either $10 \% \mathrm{FCS}, 4 \mathrm{mg} / \mathrm{mL}$ BSA, or $4 \mathrm{mg} / \mathrm{mL}$ OVA.

After IVM, oocyte maturation was evaluated based on the stage of nuclear progression (MII stage) and cortical granule migration to the periphery of the cytoplasmic membrane. For this purpose, 1,505 oocytes were divided into three experimental groups and analyzed in quadruplicate (334-450 oocytes per treatment).

Oocytes were stained as described by Cherr et al. (1988). Briefly, cumulus cells were removed with $0.2 \%$ hyaluronidase (Hyalozima ${ }^{\mathrm{TM}}$, Aspen, São Paulo, Brazil), and the zona pellucida was removed with $0.5 \%$ pronase and acid solution ( $\mathrm{pH} 2.5)$. Oocytes were then fixed in 3\% formaldehyde (Mallinckrodt, Paris, KY, USA) and incubated in blocking solution (PBS containing $1 \mathrm{mg} / \mathrm{mL}$ BSA, $100 \mathrm{mM}$ glycine [Plusone, La Jolla, CA, USA], and $0.2 \%$ sodium azide), left to sit overnight at $4{ }^{\circ} \mathrm{C}$. For permeabilization, oocytes were treated with $0.1 \%$ Triton X-100 (USB, Cleveland, $\mathrm{OH}, \mathrm{USA}$ ) and incubated in $10 \mu \mathrm{g} / \mathrm{mL}$ fluorescein isothiocyanate-conjugated Lens culinaris agglutinin and $10 \mu \mathrm{g} / \mathrm{mL}$ Hoechst 33342 . Oocytes were then mounted on slides and examined under an Olympus IX-FLA-70 epifluorescence microscope (Tokyo, Japan) to evaluate meiotic progression (excitation of 330-385 $\mathrm{nm}$ and emission of 420-490 $\mathrm{nm}$ ) and the distribution of the cortical granules (excitation of 460-490 nm and emission of $515 \mathrm{~nm}$ ). Images of each oocyte were captured with an AxioCam camera and stored using AxioVision 4.7.1 software (Carl Zeiss, Jena, Germany). MII oocytes exhibiting cortical granules homogenously distributed at the periphery were defined as matured according to the classification of Hosoe \& Shioya (1997).

IVF was performed $24 \mathrm{~h}$ after IVM in mineral oil-covered droplets of 100- $\mu$ L TALP-IVF medium (TALP medium supplemented with $30 \mu \mathrm{g} / \mathrm{mL}$ heparin, $18 \mu \mathrm{M}$ penicillamine, $10 \mu \mathrm{M}$ hypotaurine and $1.8 \mu \mathrm{M}$ epinephrine) containing $0.2 \mathrm{mM}$ pyruvate and $83.4 \mu \mathrm{g} / \mathrm{mL}$ amikacin and supplemented with $6 \mathrm{mg} / \mathrm{mL}$ BSA or OVA.

Frozen semen straws $(0.5 \mathrm{~mL})$ were thawed in water at $35{ }^{\circ} \mathrm{C}$ for $30 \mathrm{~s}$ and prepared by centrifugation on a $45 \%$ to $90 \%$ Percoll gradient at $900 \mathrm{x} g$ for $30 \mathrm{~min}$ in TALP-semen medium (TALP medium supplemented with $10 \mathrm{mM}$ acid HEPES [J.T. Baker, Phillipsburg, NJ, USA]). A 30- $\mu$ L aliquot was taken for evaluation of sperm concentration and motility. Final concentration was adjusted to $25 \times 10^{6}$ motile spermatozoa/mL with TALP-IVF medium. Next, $8 \mu \mathrm{L}$ of diluted semen were added to the droplets containing 20 to 25 oocytes, for a final concentration of $2 \times 10^{5}$ motile spermatozoa/droplet $\left(2 \times 10^{6} / \mathrm{mL}\right)$, corresponding to $8-10 \times 10^{3}$ spermatozoa per oocyte. Ooocytes were coincubated with the sperm for 18 to $20 \mathrm{~h}$ at $38.5^{\circ} \mathrm{C}$ in an atmosphere of $5 \% \mathrm{CO}_{2}$ in air under saturated humidity. The semen from the same bull was used for all treatments.

Eighteen to $20 \mathrm{~h}$ after the beginning of IVF, the cumulus cells were removed from the presumptive zygotes by successive pipetting. Zygotes were stained with $10 \mu \mathrm{g} / \mathrm{mL}$ Hoechst 33342 for $10 \mathrm{~min}$, and the presence and number of pronuclei were evaluated under an epifluorescence microscope (excitation of 330-385 $\mathrm{nm}$ and emission of $420-490 \mathrm{~nm}$ ). For this purpose, 508 presumptive zygotes were divided into groups, according to experimental design, and analyzed in quadruplicate (79-90 zygotes per treatment).

After IVF, presumptive zygotes were cultured in 4-well dishes containing $500 \mu \mathrm{L}$ of synthetic oviductal fluid (SOF) supplemented with $10 \%$ FCS, $4 \mathrm{mg} / \mathrm{mL}$ BSA, or $4 \mathrm{mg} / \mathrm{mL}$ OVA under mineral oil. Dishes were incubated in an atmosphere of $5 \% \mathrm{O}_{2}, 5 \% \mathrm{CO}_{2}$ and $90 \% \mathrm{~N}_{2}$ at $38.5^{\circ} \mathrm{C}$ in a modular chamber (Billups-Rothenberg, Del Mar, CA, USA) under saturated humidity for 7 to 9 days. 
Cleavage rate was determined approximately 32 to $36 \mathrm{~h}$ post-insemination under a stereomicroscope (magnification of $50 \mathrm{X}$ ). Cleavage was defined as the presence of two-tofour-cell embryos. Development toward blastocyst stage was evaluated on day 7 after IVF. Hatching was evaluated on day 8 after IVF. Blastocyst rate was calculated based on number of treated oocytes, and hatching rate was based on number of blastocysts. For this purpose, 2,355 bovine oocytes were divided into six experimental groups and analyzed in five replicates (314-352 oocytes per treatment).

The morphological quality of the blastocysts produced in vitro was evaluated by the proportion of total cells allocated to the inner cell mass (ICM) and trophectoderm (TE). For this purpose, 390 blastocysts derived from six experimental groups were analyzed in triplicate (52-59 blastocysts per treatment).

Blastocysts were stained according to the technique of Iwasaki et al. (1990). Briefly, the zona pellucida of the blastocysts obtained on day 7 was removed by incubation in $0.5 \%$ pronase, followed by incubation in acid solution (pH 2.5). Next, blastocysts were washed in medium without FCS and incubated on ice in $10 \mathrm{mM}$ picric acid (Reagen ${ }^{\mathrm{TM}}$, Rio de Janeiro, Brazil) and $3 \mathrm{mg} / \mathrm{mL}$ PVP. Blastocysts were then incubated in rabbit anti-bovine serum $(1: 10)$ at $38.5^{\circ} \mathrm{C}$ for $30 \mathrm{~min}$, followed by incubation in guinea pig complement (1:10) containing $10 \mu \mathrm{g} / \mathrm{mL}$ propidium iodide and $10 \mu \mathrm{g} / \mathrm{mL}$ Hoechst 33342 at $38.5^{\circ} \mathrm{C}$ for an additional $30 \mathrm{~min}$. Blastocysts were placed on glass slides, covered with glass coverslips and examined under an epifluorescence microscope (excitation of 340-380 nm and emission of $430 \mathrm{~nm}$ ) to count the number of ICM cells, whose nuclei were stained blue with Hoechst 33342, and TE cells, whose nuclei stained pink with propidium iodide and Hoechst (Koo et al., 2002).

In a preliminary experiment, three concentrations of OVA were used for IVM. Effects were evaluated by means of nuclear maturation and cortical granule migration. IVM medium was supplemented with 2, 4 or $6 \mathrm{mg} / \mathrm{mL}$ OVA. Data from three replicates were used, for a total of 676 oocytes.

In order to determine the effects of supplementation by different protein sources during the three steps of in vitro embryo production (IVM, IVF and IVC), an experimental design was performed. Combinations of the same supplement for IVM+IVC were combined with BSA or OVA for IVF.

The effect of the source of protein supplementation on IVM was assessed by supplementing the IVM medium with $10 \% \mathrm{FCS}, 4 \mathrm{mg} / \mathrm{mL}$ of BSA or $4 \mathrm{mg} / \mathrm{mL}$ of OVA. Oocytes were evaluated for nuclear maturation and cortical granule migration in quadruplicate, for a total of 1,168 oocytes.

The effect of treatment on pronuclear formation during IVF was evaluated using a factorial design, which consisted
Experimental design

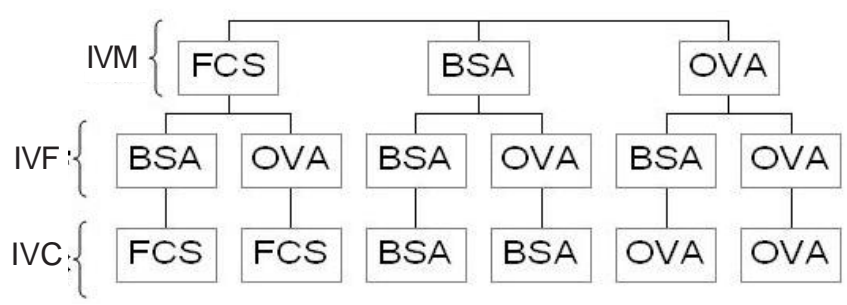

Figure 1 - Schematic of the experimental design used to evaluate the performance of OVA compared with BSA and FCS in IVM+IVC and OVA compared with BSA for IVF of bovine oocytes.

of three sources of supplementation during IVM (FCS, BSA and OVA) and two sources of supplementation during IVF (BSA and OVA). Three replicates per group were performed, for a total of 508 oocytes.

For the IVC step, embryo development (cleavage, blastocyst and hatching rates) and cell number (ICM, TE and total number) results were determined and analyzed by a factorial design consisting of three sources of combined supplementation during IVM and IVC (FCS, BSA and OVA) and two sources of supplementation during IVF (BSA and OVA), for a total of six experimental groups. For IVC, five replicates per group were performed, for a total of 2,003 oocytes. To determine embryo cell number, 324 embryos were stained ( 51 to 59 embryos per group).

Nuclear maturation and cortical granule migration results were analyzed by ANOVA. Pronuclear formation, embryo development rates (cleavage, blastocyst and hatching rates), embryo cell numbers, and their interaction were analyzed by ANOVA. Means were compared by the Tukey test. The equality of variance was tested by Levene's test. Statistical analysis was performed using the Statistical Analysis System (SAS Institute, Inc., 1989). A level of significance of $5 \%$ was used for all experiments.

\section{Results and Discussion}

Appropriate in vitro bovine embryo production (IVP) systems with high sanitary standards are fundamental in commercial bovine IVP settings, and they depend largely on FCS and BSA's substitution. Especially due to the preponderance of Nellore in its herd, Brazil has developed an expertise in bovine biotechnology and has successfully applied it towards large-scale in vitro bovine embryo production (Pontes et al. 2009, 2010). For the first time, the introduction of OVA was proposedas a supplement for bovine embryo IVP to improve the sanitary quality of 
bovine embryos produced in vitro. The adequate concentration and the effects of OVA in the three main steps (IVM, IVF and IVC) of bovine embryo IVP were evaluated by measuring the formation of pronuclei and embryo development rates and embryo cell staining.

Different concentrations of ovalbumin $(2,4$ or $6 \mathrm{mg} / \mathrm{mL})$ for the IVM of bovine oocytes were evaluated by assessing nuclear maturation and cortical granule migration (Table 1). Similar results were obtained with 4 and $6 \mathrm{mg} / \mathrm{mL}$ of ovalbumin. Four $\mathrm{mg} / \mathrm{mL}$ for IVM and for IVC, which are the same amounts used for BSA, were preferred.

In the next experiment, IVM was performed using different protein sources (FCS, BSA, OVA), and nuclear maturation and cortical granule migration were evaluated (Table 2). For FCS, BSA and OVA, similar rates ( $\mathrm{P}>0.05)$ of nuclear maturation ( 74.01 to $78.78 \%$ ) and cortical granule migration (58.89 to $65.48 \%$; Table 2) were observed. Therefore, we can conclude that OVA, FCS, and BSA supplementation enables similar nuclear and cytoplasmic maturation.

To observe the effect of protein source during IVM and IVF, the rate of pronucleus formation and the number of pronuclei formed were evaluated 18 to $20 \mathrm{~h}$ postinsemination. No statistical interaction $(\mathrm{P}>0.05)$ between IVM and IVF was observed when different protein sources were compared. However, higher rates $(\mathrm{P}<0.05)$ of two pronuclei were obtained when FCS was used for IVM (79.97\%) compared with BSA (48.06\%) and OVA (38.35\%) and when BSA was used for IVF (59.4\%) compared to OVA $(51.52 \%)$

As for the pronuclear formation rates, no interaction $(\mathrm{P}>0.05)$ between IVM+IVC and IVF occurred. Data were then statistically compared using protein supplementation

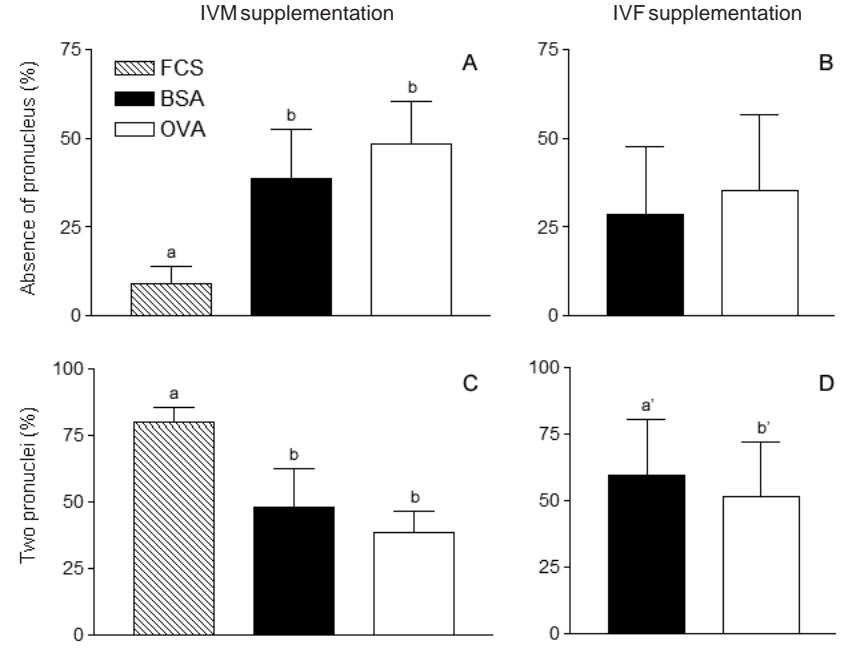

Different letters (a, b and a', b') above the bars indicate significant differences $(\mathrm{P}<0.05)$ between IVM and IVF supplementation, respectively. Bars depict means and whiskers depict standard deviations.

Figure 2 - Rates of the absence of pronuclei (A and B) or the presence of two pronuclei (C and D) in zygotes produced from oocytes matured in medium supplemented with fetal calf serum (FCS), bovine serum albumin (BSA) or ovalbumin (OVA) (A and C) or fertilized in medium supplemented with BSA or OVA (B and D).

for IVM+IVC (FCS $[\mathrm{n}=654]$, BSA $[\mathrm{n}=684]$ and OVA $[\mathrm{n}=665])$ and protein supplementation for IVF (BSA $[\mathrm{n}=1006]$ and OVA $[\mathrm{n}=997])$.

Cleavage rates were similar $(\mathrm{P}>0.05)$ between treatments when FCS (78.53\%), BSA (75.64\%) or OVA $(69.19 \%)$ was used for IVM+IVF and BSA $(76.72 \%)$ or OVA $(72.18 \%)$ was used for IVF. IVM+IVC supplementation with BSA or FCS resulted in similar blastocyst rate. Nonetheless, OVA supplementation during IVM+IVC resulted in lower $(\mathrm{P}<0.05)$

Table 1 - Nuclear maturation and cortical granule migration after in vitro maturation (IVM) of oocytes for $24 \mathrm{~h}$ in medium supplemented with 2,4 or $6 \mathrm{mg} / \mathrm{ml}$ ovalbumin

\begin{tabular}{cccc}
\hline Ovalbumin $(\mathrm{mg} / \mathrm{mL})$ & $\mathrm{N}$ & Nuclear maturation $(\% \pm$ SD) & Cortical granule migration $(\% \pm$ SD) \\
\hline 2 & 159 & $50.83 \pm 8.42 \mathrm{~b}$ & $20.15 \pm 2.31 \mathrm{~b}$ \\
4 & 167 & $82.66 \pm 0.63 \mathrm{a}$ & $54.21 \pm 5.04 \mathrm{a}$ \\
6 & 170 & $77.05 \pm 5.82 \mathrm{a}$ & $47.65 \pm 4.16 \mathrm{a}$ \\
Total & 496 & - & - \\
\hline
\end{tabular}

$\mathrm{N}=$ number of oocytes; $\mathrm{SD}=$ standard deviation

$\mathrm{a}, \mathrm{b}=$ different superscripts within columns indicate differences $(\mathrm{P}<0.05)$ between ovalbumin concentrations during IVM.

Table 2 - Nuclear maturation and cortical granule migration of oocytes matured in vitro for $24 \mathrm{~h}$ in medium supplemented with $10 \%$ fetal calf serum (FCS), $4 \mathrm{mg} / \mathrm{mL}$ bovine serum albumin (BSA) or $4 \mathrm{mg} / \mathrm{mL}$ ovalbumin (OVA)

\begin{tabular}{|c|c|c|c|}
\hline IVM supplement & $\mathrm{N}$ & Nuclear maturation $(\% \pm \mathrm{SD})$ & CG migration $(\% \pm \mathrm{SD})$ \\
\hline FCS & 384 & $75.66 \pm 2.88$ & $64.35 \pm 5.56$ \\
\hline BSA & 450 & $74.01 \pm 4.41$ & $58.89 \pm 2.88$ \\
\hline OVA & 334 & $78.78 \pm 4.32$ & $65.48 \pm 11.50$ \\
\hline Total & 1168 & - & - \\
\hline
\end{tabular}


blastocyst (20.40\%) and hatching (23.02\%) rates than FCS (30.47 and $40.78 \%$ for blastocyst and hatching rates, respectively) and BSA ( 25.73 and $34.82 \%$ for blastocyst and hatching rates, respectively) (Figure 3).

Furthermore, the use of OVA during IVF resulted in lower blastocyst development and hatching rates $(22.15 \%$ and $28.93 \%$, respectively) than BSA (28.91 and $36.82 \%$ for blastocyst and hatching rates, respectively).

Because there was interaction between IVM+IVC and IVF supplementation, the six experimental groups were compared using the supplement associations (Table 3). When OVA was used as the supplement for IVF, the use of FCS or BSA as supplements during IVM and IVC resulted in higher $(\mathrm{P}<0.05) \mathrm{ICM}, \mathrm{TE}$ and total cell number compared with OVA for IVM+IVC. When OVA was used as the supplement for IVM+IVC, the use of BSA for IVF resulted in higher $(\mathrm{P}<0.05) \mathrm{ICM}$, TE and total cell number compared with OVA as a supplement for IVF. Therefore, supplementation with OVA during IVM+IVC and IVF decreased embryo quality, as measured by the number of ICM, TE and total cells in bovine blastocysts.

The different in vitro culture systems that support the development of embryos can be classified according to the presence or absence of protein sources. Media supplemented with FCS are considered undefined, media supplemented with BSA are classified as semi-defined, and media with synthetic supplements are considered defined in their composition. Although defined media would be the
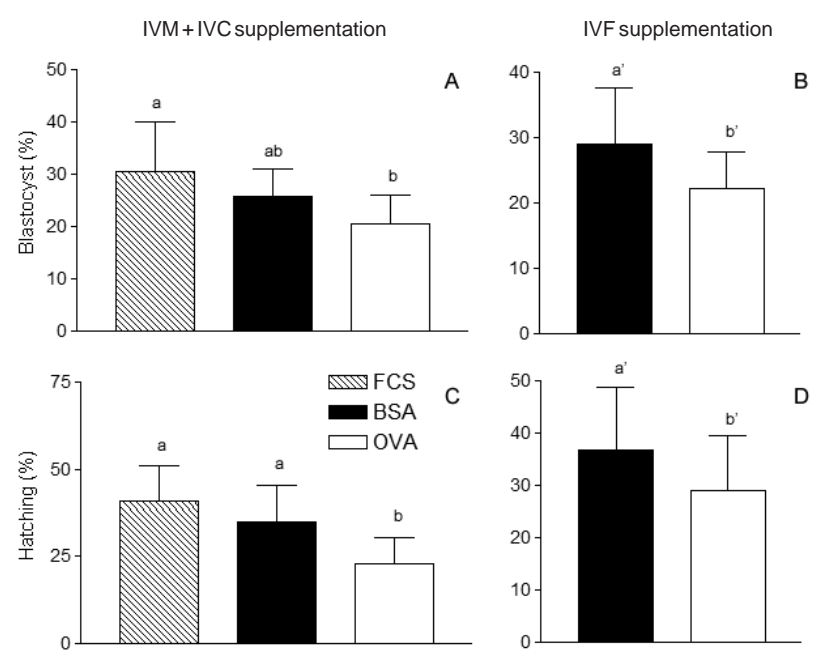

Different letters (a, b and a', b') above the bars indicate significant differences $(\mathrm{P}<0.05)$ among the supplements used for IVM+IVC and for IVF, respectively. Bars depict means, and whiskers depict standard deviations.

Figure 3 - Effect of fetal calf serum (FCS), bovine serum albumin (BSA) or ovalbumin (OVA) supplementation in IVM plus IVC medium or in IVF medium on blastocyst (A and $\mathrm{B})$ and hatching $(\mathrm{C}$ and $\mathrm{D})$ rates. ideal system for the in vitro culture of oocytes and embryos, supplementation of culture media with protein sources of animal origin provides the best results from oocyte maturation to the final step of in vitro embryo development (Vanroose et al., 2001). Synthetic supplements, such as PVA, PVP and Ficoll, can successfully replace serum during IVM when IVC is performed using $5 \mathrm{mg} / \mathrm{mL}$ of BSA and $2.5 \%$ FCS (Mingoti et al., 2009). Synthetic macromolecules such as polyvinyl alcohol (PVA) and polyvinylpyrrolidone (PVP) have been proposed as substitutes for animal proteins in embryo culture media, but lower embryo development has been observed (Lim et al., 2007).

Recently, the use of plant protein hydrolysates or plant peptones (consisting of oligopeptides and free amino acids from wheat and cotton) has been evaluated. Even though similar rates of embryo development were observed, the embryo sex ratio was skewed towards male embryos and needs to be clarified (George et al., 2009). In this study, the aim was to avoid cross-contamination caused by supplements of bovine origin and evaluate the possibility of using OVA, a well-characterized protein supplement of animal origin but with no sanitary risks.

Maturation is complete when the oocyte can be fertilized and develop into an embryo (Rizos et al., 2003). The analysis of nuclear maturation and cortical granule migration (a sign of cytoplasmic maturation) found no significant differences $(\mathrm{P}>0.05)$ between the different protein sources (FCS, BSA, and OVA). The rate of nuclear maturation ranged from 74.01 to $78.78 \%$ in the different groups, and these rates were similar to the ones reported by other investigators (approximately 80\%) for the IVM of oocytes in an undefined medium (Kim et al., 1997).

The success of IVF in cattle depends on the appropriate preparation of both semen and oocytes that favors the metabolic activity of male and female gametes (Brackett et al. 1981). Regarding the rate of pronucleus formation and the number of pronuclei formed, significant differences were observed in the proportion of the absence of a pronucleus and the development of two pronuclei. The capacity of a zygote to form pronuclei depends on the quality of oocyte maturation, and, in this study, FCS was the most efficient protein source for IVM, compared with BSA and OVA. Furthermore, the rate of two pronuclei when oocytes were subjected to IVF with BSA was higher than with OVA, regardless of the supplement used for IVM (FCS, BSA or OVA).

Variations in embryo development results are observed among laboratories due to differences in the procedures, protocols and substances (Gordon, 1994). In the present experiment, no significant $(\mathrm{P}>0.05)$ differences in cleavage 
rates were observed among treatments. Similar cleavage rates were reported by Pinyopummintr \& Bavister (1994), who compared semi-defined or undefined culture media with chemically defined media.

In the literature, the results obtained with BSA and FCS are controversial. The absence of BSA in SOF during IVM increased morulae and blastocyst production (Ali \& Sirard 2002), while the presence of BSA-V and FCS during IVC reduced the percentage of morulae and blastocysts, compared with the use of purified BSA, fatty acid-free (FAF) BSA and ovalbumin (Ali \& Sirard, 2002). Similarly, Carolan et al. (1995) reported that the removal of BSA from the SOF medium during IVC results in significantly lower blastocyst yields on days 6, 7 and 8. In contrast, Lonergan et al. (1998) observed that FCS significantly accelerated embryo development, triggering premature blastulation and improving blastocyst quality, as demonstrated by an increased total cell number and hatching rate. In media containing FCS, hatching is facilitated by the presence of plasminogen, which assists in the degradation of the zona pellucida (Kaaekuahiwi \& Menino, 1990). However, prolonged supplementation with FCS in the culture medium leads to morphological alterations and has deleterious effects on the embryo, affecting cell density, color, size, metabolism and the expression of numerous genes (Krisher et al., 1999; Shamsuddin \& Rodriguez-Martinez, 1994; Hall, 1999). Additional harmful alterations include ultrastructural rupture of organelles, such as mitochondria, among others (Hasler, 2000; Farin et al. 2001). Metabolic alterations, such as an abnormally large number of lipid droplets in morulae and blastocysts, have also been reported for embryos cultured in FCS-supplemented medium compared with serum-free medium (Abe et al., 1999).

One of the most practical and efficient approaches to evaluate the embryo quality of blastocysts produced in vitro is the quantification of the total number of cells in the embryo and the proportion of cells allocated into the ICM and TE. Bovine embryos of superior quality should have a total cell number as close as possible to the number of cycles. Under the conditions of the present experiment, this number would range from 64 to 128 cells. Total cell number ranged from 56.04 to 84.86 cells per embryo for the treatments using different protein supplement sources. Given the interval of analysis, this mean was distinctly lower than what was expected for the chronological age of the blastocysts.

The use of FCS and BSA during IVM+IVC was efficient for in vitro embryo production, regardless of the protein source used during IVF (BSA or OVA). However, OVA supplementation during all three steps (IVM, IVF and IVC) resulted in embryos with a smaller total number of cells $(<64$ cells, corresponding to the sixth cell cycle), which were classified as low quality. Similar lower embryo quality was observed when FCS and BSA were replacedby PVA during IVC. A mean total number of 81 cells for blastocysts was produced in medium containing FCS, compared with 156 cells for medium supplemented with BSA and 76 cells for medium containing PVA (Kuran et al., 2001).

\section{Conclusions}

The present results show that it is possible to produce bovine embryos in the absence of FCS or BSA using OVA as a protein source. Although the quantity and quality of bovine blastocysts using only OVA throughout IVP were lower than those obtained in the presence of FCS and BSA, OVA used during IVF and IVC was able to maintain blastocyst rate, blastocyst development, and hatching rates when FCS was used during IVM. Further studies combining OVA with growth factors, vitamins and hormones during bovine IVP should be performed to improve culture conditions and define efficient systems for bovine embryo IVP.

\section{Acknowledgements}

The authors are grateful to Roberta Vantini for technical assistance. This study was supported by FAPESP (Foundation for the Support of Research of the State of São Paulo), Brazil, and CNPq (National Council of Scientific and Technological Development), Brazil.

\section{References}

ABE, H.; YAMASHITA, S.; ITOH, T. et al. Ultrastructure of bovine embryos developed from in vitro - matured and - fertilized oocytes: comparative morphological evaluation of embryos cultured either in serum-free medium or in serum-supplemented medium. Molecular Reproduction Development, v.53 p.325-335, 1999

ALI, A.A.; SIRARD, M.A. Effect of the absence of various protein supplements on further development of bovine oocytes during in vitro maturation. Biology of Reproduction, v.66, p.901-905, 2002 .

BAHR, J.M.; JOHNSON, P.A. Reproduction in poultry. In: CUPPS, P.T. (Ed.) Reproduction in domestic animals. 4.ed. San Diego: Academic Press, 1991. p.555-575.

BARLIAN, A.; GANASSIN, R.C.; TOM, D. et al. A comparison of bovine serum albumin and chicken ovalbumin as supplements for the serum-free growth of Chinook salmon embryo cells. Cell Biology International, v.17, p.677-684, 1993.

BATT, P.A.; GARDNER, D.K.; CAMERON, A.W. Oxygen concentration and protein source affect the development of preimplantation goat embryos in vitro. Reproduction Fertility and Development, v.3, p.601-607, 1991 
BAVISTER, B.D. Culture of preimplantation embryo: facts and antifacts. Human Reproduction Update, v.1, p.91-148, 1995.

BAVISTER, B.D.; ROSE-HELLEKANT, T.A.; PINYOPUMMINTR, T. Development of in vitro matured/in vitro fertilized bovine embryos into morulae and blastocysts in defined culture media. Theriogenology, v.37, p.124-46, 1992.

BESLER, J.K.; MINE, A.R. Major hen's egg white: ovomucoid. In: Symposium on food. New York: CRC Press, 1999. p.137-146.

BRACKETT, B.G.; SEIDEL JUNIOR, G.E.; SEIDEL, S.M. (Ed.) Technologies in animal breeding. New York: Academic Press, 1981. 291p.

CAROLAN, C.; LONERGAN. P.; VAN LANGENDONCKT, A. et al. Factors affecting bovine embryo development in synthetic oviduct fluid following oocyte maturation and fertilization in vitro. Theriogenology, v.43, p.1115-28, 1995.

CHAUDHRY, M.A.; VITALIS, T.Z.; BOWEN, B.D. et al. Basal medium composition and serum or serum replacement concentration influences on the maintenance of murine embryonic stem cells. Cytotechnology, v.58, p.173-179, 2008.

CHERR, G.N.; DROBNIS, E.Z.; KATZ, D.F. Localization of cortical granule constituents before and after exocytosis in the hamster egg. The Journal of Experimental Zoology, v.246, p.81-93, 1988.

DALVIT, G.; LLANES, S.P.; DESCALZO, A. et al. Effect of alphatocopherol and ascorbic acid on bovine oocyte in vitro maturation. Reproduction in Domestic Animals, v.40, p.93-97, 2005.

FARIN, P.W.; CROSIER, A.E.; FARIN, C.E. Influence of in vitro systems on embryo survival and fetal development in cattle. Theriogenology, v.55, p.151-170, 2001.

GARDNER, D.K.; LANE, M. Embryos culture systems. In: GARDNER, D.K.; TROUNSON, A.O. (Eds.) New York: CRC Press, 1993. p.84-105.

GEORGE, F.; KERSCHEN, D.; VAN NUFFEL, A. et al. Plant protein hydrolysates (plant peptones) as substitutes for animal proteins in embryo culture medium. Reproduction, Fertility and Development, v.21, p.587-598, 2009.

GORDON, I. Laboratory production of cattle embryos. Cambridge: Cambridge University Press, 1994. p.30-142.

GUERIN, B.; LE GUIENNE, B.; THIBIER, M. Absence de contamination microbiologique des embryos bovine fécondés in vitro. Bull Academic Veterinarian France, v.61, p.513-520, 1988.

HALL, A.G. The role of glutathione in the regulation of apoptosis. European Journal of Clinical Investigation, v.29, p.238-245, 1999.

HASLER, J.F. In vitro production of cattle embryos problems with pregnancies and parturition. Human Reproduction, v.15, p.47-58, 2000 .

HOLM, P.; BOOTH, P.J.; CALLESEN, H. Kinetics of early in vitro development of bovine in vivo and in vitro derived zygotes produced and/ or cultured in chemically defined or serum containing media. Reproduction, v.123, p.553-565, 2002.

HOSOE, M.; SHIOYA, Y. Distribution of cortical granules in bovine oocytes classified by cumulus complex. Zygote, v.5, p.371-376, 1997.

IWASAKI, S.; YOSHIBA, N.; USHIJIMA, H. et al. Morphology and proportion of inner cell mass of bovine blastocysts fertilized in vitro and in vivo. Journal of Reproduction and Fertility, v.90, p.279-285, 1990.

KAAEKUAHIWI, M.A.; MENINO JUNIOR, A.R. Relationship between plasminogen activator production and bovine embryo development in vitro. Journal of Animal Science, v.68, p.2009-2014, 1990.

KANE, M.T.; HEADON, D.R. The role of commercial bovine serum albumin preparations in the culture of one-cell rabbit embryos to blastocysts. Journal of Reproduction and Fertility, v.60, p.469-475, 1980.

KIM, K.S.; MINAMI, N.; YAMADA, M. et al. Follicular cells affect the fertilizability and developmental competency of bovine oocytes in vitro. Reproduction, Fertility and Development, v.9, p.763-766, 1997.
KOO, D.B.; KANG, Y.K.; CHOI, Y.H. et al. Aberrant allocations of inner cell mass and trophectoderm cells in bovine nuclear. Biology of Reproduction, v.67, p.487-492, 2002.

KRISHER, R.L.; LANE, M.; BAVISTER, B.D. Developmental competence and metabolism of bovine embryos cultured in semidefined and defined culture media. Biology of Reproduction, v.60, p.1345-1352, 1999.

KURAN, M.; ROBINSON, J.J.; TAINES, M.E. et al. Development and de novo protein synthetic activity of bovine embryos produced in vitro in different culture systems. Theriogenology, v. 55, p.593-606, 2001

LIM, K.T.; JANG, G.; KO, K.H. et al. Improved in vitro bovine embryo development and increased efficiency in producing viable calves using defined media. Theriogenology, v.67, p.293-302, 2007.

LONERGAN, P.; FAIR, T.; KHATIR, H. et al. Effect of protein synthesis inhibition before or during in vitro maturation on subsequent development of bovine oocytes. Theriogenology, v.50, p.417-431, 1998.

MINGOTI, G.Z.; CAIADO CASTRO, V.S.; MÉO, S.C. et al. The effect of interaction between macromolecule supplement and oxygen tension on bovine oocytes and embryos cultured in vitro. Zygote, v.17, p.321-328, 2009.

NEUBER, E.; LUETJENS, C.M.; CHAN, A.W.S. et al. Analysis of DNA fragmentation of in vitro cultured bovine blastocysts using TUNEL. Theriogenology, v.57, p.2193-202, 2002.

PINYOPUMMINTR, T.; BAVISTER, B.D. Development of bovine embryos in a cell-free culture medium: effects of type of serum, of its inclusion and heat inactivation. Theriogenology, v.41, p.1241-1249, 1994.

PONTES, J.H.; NONATO-JUNIOR, I.; SANCHES, B.V. et al. Comparison of embryo yield and pregnancy rate between in vivo and in vitro methods in the same Nelore (Bos indicus) donor cows. Theriogenology, v.71, p.690-697, 2009.

PONTES, J.H.; SILVA, K.C.; BASSO, A.C. et al. Large-scale in vitro embryo production and pregnancy rates from Bos taurus, Bos indicus, and indicus-taurus dairy cows using sexed sperm. Theriogenology, v.74, p.1349-1355, 2010.

PRATTEN, M.K.; BROOKE, A.M.; BROOME, S.C. et al. The effect of epidermal growth, factor insulin and transferrin on the growth-promoting properties of serum depleted by repeated culture of post implantation rat embryos. Development, v.104, p.137-145, 1988 .

RIZOS, D.; GUTIERREZ-ADAN, A.; PEREZ-GARNELO, S. et al. Bovine embryo culture in the presence or absence of serum: implications for blastocyst development, cryotolerance, and messenger RNA expression. Biology of Reproduction, v.68, p.236-243, 2003

SHAMSUDDIN, M.; RODRIGUEZ-MARTINEZ, H. Fine structure of bovine blastocysts developed either in serum-free medium or conventional co-culture with oviduct epithelial cells. Journal of Veterinary Medicine, v.41, p.307-316, 1994.

TAKAHASHI, Y.; FIRST, N.L. In vitro development of bovine one-cell embryos: influence of glucose, lactate, pyruvate, amino acids and vitamins. Theriogenology, v.37, p.963-978. 1992.

VANROOSE, G.; VAN SOOM, A.; DE KRUIF, A. From co-culture to defined medium: state of the art and practical considerations. Reproduction in Domestic Animals, v.36, p.25-28, 2001.

WATSON, A.J.; DE SOUSA, P.; CAVENEY, A. et al. Impact of bovine oocyte maturation media on oocyte transcript levels, blastocyst development, cell number, and apoptosis. Biology of Reproduction, v.62, p.355-364, 2000.

WRENZYCKI, C.; HERMANN, D.; CARNWATH, J.W. et al. Alterations in the relative abundance of gene transcripts in preimplantation bovine embryos cultured in medium supplemented with either serum or PVA. Molecular Reproduction Development v. 53, p. $8-18,1999$. 